\title{
Radiological profile of children under 2 years of age from South India with urinary tract infection
}

\author{
*Pratima Piduru ${ }^{1}$, M Penchala Reddy ${ }^{2}$, Raja M Sekhar Reddy ${ }^{3}$, M Vijaya Lakshmi ${ }^{2}$ \\ Sri Lanka Journal of Child Health, 2016; 45(3): 169-171
}

\begin{abstract}
Objective: To assess the proportion of children less than 2 years of age with urinary tract infection (UTI) having structural anomalies detected by screening ultrasonography (USG) and voiding cystourethrography (VCUG).
\end{abstract}

Method: A prospective observational study was done in a tertiary care hospital in South India from May 2014 to April 2015 on children less than 2 years of age, attending the paediatric or paediatric urology outpatient department and paediatric and neonatal wards, with symptoms suggestive of UTI. All urine culture positive cases were included in the study except for cases who had undergone operative procedures and catheterisation of urinary tract. Screening USG and VCUG were performed.

Results: The radiological profile of UTI was analysed in the study group comprising 216 children less than 2 years of age. Radiological abnormalities were detected in $82(38 \%)$ cases with female predominance. Fifty three $(64.6 \%)$ of the abnormalities were identified by USG and 41 $(50 \%)$ by VCUG. On USG, cystitis and pyelonephritis were the common abnormalities seen whilst vesicoureteral reflux (VUR) and posterior urethral valves (PUV) were the common abnormalities seen on VCUG. The 34 children with VUR had grades I and II reflux in $73.4 \%$, grade III and IV reflux in $23.4 \%$ and grade $\mathrm{V}$ reflux in $3.2 \%$ cases. Four $(11.7 \%)$ children had bilateral reflux.

${ }^{1}$ Assistant Professor, Department of Paediatric Nephrology, ${ }^{2}$ Assistant Professor, Department of Pathology, ${ }^{3}$ Senior Resident, Narayana Medical College, Nellore, Andhra Pradesh, India

*Correspondence:pratimaneph2007@rediffmail.com

(Received on 04 September 2015: Accepted after revision on 27 October 2015)

The authors declare that there are no conflicts of interest

Personal funding was used for this project.

Open Access Article published under the Creative Commons Attribution CC-BY (c) (P)
Conclusions: Radiological abnormalities were detected in $38 \%$ children less than 2 years of age with UTI by screening USG and VCUG.

DOI: http://dx.doi.org/10.4038/sljch.v45i3.8006

(Key words: Urinary tract infection, urine culture and sensitivity, voiding cystourethrography, ultrasonography, vesico-ureteral reflux)

\section{Introduction}

Urinary tract infections (UTIs) are common bacterial infections in children ${ }^{1}$. It is estimated that $8 \%$ girls and $2 \%$ boys acquire UTIs in childhood ${ }^{2}$. Early diagnosis is important to preserve renal function of the growing kidney ${ }^{3}$. UTI is one of the most important risk factors in the development of renal insufficiency or end stage renal disease ${ }^{4}$.

\section{Objective}

To analyse the proportion of children less than 2 years of age with UTI having structural anomalies detected by screening ultrasonography (USG) and voiding cystourethrography (VCUG).

\section{Method}

This was a prospective observational study done in a tertiary care hospital in South India from May 2014 to April 2015. All children less than 2 years of age attending the paediatric or paediatric urology outpatient department, and paediatric and neonatal wards with symptoms suggestive of UTI were screened with urine microscopic examination and dipstick (leukocyte esterase, nitrate) test by a clinical pathologist. Children with positive screening tests were subjected to urine culture and sensitivity. Urine for cultures were collected by different methods depending on age and technical feasibility i.e. midstream clean catch method, catheter sample, suprapubic aspiration. UTI was considered according to method of collection. Suprapubic aspirations and transurethral catheterisation: $>50,000$ colony forming units $(\mathrm{CFU}) / \mathrm{ml}$, clean catch: $>100,000 \mathrm{CFU} / \mathrm{ml}$ are necessary for diagnosis of $\mathrm{UTI}^{4}$. On the basis of the urine culture and sensitivity reports, each child was started on appropriate antibiotics. Children who had undergone operative procedures and catheterisation of urinary tract were excluded from the study. Written consent was taken from the 
$\underline{\text { Radiological profile of children under } 2 \text { years of age....Sri Lanka Journal of Child Health, 2016; 45(3): } 169-171}$

parents or guardians before enrolling them in the study. Ethical clearance for the study was obtained from Ethical Review Committee of the Narayana Medical College and Hospital.

Screening renal USG was done on all children included in the study and the findings documented. Each child was followed up until the resolution of symptoms. After confirming sterile urine culture when symptoms resolved, contrast VCUG was performed. Sensitive oral antibiotics were continued till the VCUG. The findings of VCUG were noted. All results were analysed using descriptive statistics.

\section{Results}

The radiological profile of UTI was analysed in the study group which comprised 216 children less than 2 years of age. The age and gender of the study population is shown in Table 1 .

Table 1

Age and gender of study population $(n=216)$

\begin{tabular}{|l|c|c|}
\hline \multicolumn{1}{|c|}{ Age } & $\begin{array}{c}\text { Male } \\
\text { No. }(\%)\end{array}$ & $\begin{array}{c}\text { Female } \\
\text { No. }(\%)\end{array}$ \\
\hline$<1$ month & $15(06.9)$ & $08(03.7)$ \\
\hline $1-6$ months & $37(17.1)$ & $24(11.1)$ \\
\hline 6 months-1 year & $38(17.6)$ & $39(18.1)$ \\
\hline $1-2$ years & $26(12.0)$ & $29(13.4)$ \\
\hline \multicolumn{1}{|c|}{ Total } & $\mathbf{1 1 6 ( 5 3 . 7 )}$ & $\mathbf{1 0 0}(\mathbf{4 6 , 3 )}$ \\
\hline
\end{tabular}

Radiological abnormalities were detected by USG and VCUG in $82(38 \%)$ children. Abnormalities were found in 46 of $100(46 \%)$ females compared to 36 of $116(31 \%)$ males. Abnormalities detected on USG are shown in Table 2.

Abnormalities detected on VCUG are shown in Table 3.
Table 2

Abnormalities detected by USG $(n=216)$

\begin{tabular}{|l|l|}
\hline \multicolumn{1}{|c|}{ USG finding } & No. (\%) \\
\hline Bladder wall thickening (cystitis) & $27(12.5)$ \\
\hline Pyelonephritis & $12(06.5)$ \\
\hline Vesicoureteral reflux & $09(04.1)$ \\
\hline Urolithiasis & $04(01.8)$ \\
\hline Duplication of collecting system & $01(00.4)$ \\
\hline \multicolumn{1}{|c|}{ Total } & $\mathbf{5 3 ( 2 4 . 5 )}$ \\
\hline
\end{tabular}

USG: ultrasonography

Table 3

Abnormalities detected on VCUG $(n=216)$

\begin{tabular}{|c|c|}
\hline VCUG finding & No. $(\%)$ \\
\hline Vesicoureteral reflux & $34(15.7)$ \\
\hline Posterior urethral valve & $05(2.3)$ \\
\hline Duplication of collecting system & $01(0.4)$ \\
\hline Stone as filling defect & $01(0.4)$ \\
\hline Total & $41(19.0)$ \\
\hline
\end{tabular}

VCUG: voiding cystourethrography

Two cases of PUV in neonates, detected by antenatal USG, were confirmed postnatally by VCUG. Vesicoureteral reflux (VUR) was more common in females $20(58.8 \%)$ compared to males $14(41.2 \%)$. Grading of VUR is shown in Table 4.

Table 4

Grading of VUR $(n=34)$

\begin{tabular}{|c|c|}
\hline Grade of VUR & No. (\%) \\
\hline I & $16(47.0)$ \\
\hline II & $09(26.4)$ \\
\hline III & $04(11.7)$ \\
\hline IV & $04(11.7)$ \\
\hline V & $01(03.2)$ \\
\hline Total & $\mathbf{3 4}(\mathbf{1 0 0 . 0})$ \\
\hline
\end{tabular}

VUR: vesicoureteral reflux

Bilateral reflux was seen in $4(11.7 \%)$ of the total VUR cases. The age distribution of the various grades of VUR is shown in Table 5.

Table 5: Age distribution of various grades of VUR $(n=34)$

\begin{tabular}{|l|c|c|c|c|c|c|}
\hline \multirow{2}{*}{ Age } & \multicolumn{7}{c|}{ Grade of VUR } \\
\cline { 2 - 7 } & I & II & III & IV & V & Total (\%) \\
\hline$<1$ month & 4 & 0 & 2 & 0 & 0 & $06(17.6)$ \\
\hline 1-6 months & 9 & 5 & 1 & 2 & 0 & $17(50.0)$ \\
\hline 6 months - 1 year & 0 & 2 & 0 & 1 & 0 & $03(08.8)$ \\
\hline 1-2 years & 3 & 2 & 1 & 1 & 1 & $08(23.6)$ \\
\hline
\end{tabular}

\section{Discussion}

In the study by Ghaemi $\mathrm{S}$. et $\mathrm{al}^{5}$, using ultrasonography and VCUG for imaging, the reported incidence of radiological abnormalities was $17.4 \%$ compared to $38 \%$ in our study. The lower incidence reported by Ghaemi $\mathrm{S}$. et $\mathrm{al}^{5}$ is probably due to the wider age range ( 2 weeks to 12 years) used in their study. In the study by Ginsburg $\mathrm{CM}$ et $\mathrm{al}^{6}$, using ultrasonography and VCUG for imaging, there were abnormalities of urinary tract in $45 \%$ of females and $7 \%$ of males. Whilst the incidence of abnormalities among females was comparable with the present study, the proportion of males having radiological abnormalities (7\%) 
was low compared to the present study. Panahi Y et $\mathrm{al}^{7}$, using ultrasonography and VCUG for imaging, noted radiological abnormalities in $63 \%$ of the cases with male preponderance which contrasts with the female preponderance in our study.

In our study, bladder wall thickening (cystitis) and pyelonephritis were detected only by USS, urolithiasis mainly by USS, duplication of collecting system equally by USG and VCUG, VUR mainly by VCUG and PUV only by VCUG. Cohen M. et $\mathrm{al}^{8}$ in their prospective study found VUR in $10 \%$ of cases. Ginsburg CM et $\mathrm{al}^{6}$ found VUR in $19 \%$ of cases, $13 \%$ having bilateral reflux. Prevalence study by Chow $\mathrm{CB}$ et $\mathrm{al}^{9}$ noted VUR in $18 \%$ of cases. In the study by Siegel $\mathrm{S} R$ et $\mathrm{al}^{10}$, VUR was noted in $18 \%$ of cases, $48 \%$ of them having bilateral reflux. In our study VUR was detected in $15.7 \%$ of cases, $11.7 \%$ having bilateral reflux. In the study by Drew JH et $\mathrm{al}^{11}, 50 \%$ of neonates had VUR whereas in the present study $26.1 \%$ neonates had VUR. In the study by Saleh SI et $\mathrm{al}^{12}$, of the $15.5 \%$ with VUR, $26.4 \%$ had grade I reflux, $7.5 \%$ had grade II reflux, 5.7\% had grade III reflux and $3.8 \%$ had grade IV reflux. In the present study, of the $15.7 \%$ children with VUR, $47.0 \%$ had grade I reflux, $26.4 \%$ had grade II reflux, $11.7 \%$ had grade III reflux and $3.2 \%$ had grade IV reflux.

\section{Conclusion}

Radiological abnormalities were detected in 38\% children less than 2 years old with UTI by USG and VCUG in a tertiary care hospital in South India.

\section{References}

1. Watson AR, Taylor CM, McGraw M. Disorders of the urinary system. In: Neil McIntosh, Peter Helms, Rosalind Smyth, editors. Forfar and Arneil's Textbook of Pediatrics, $6^{\text {th }}$ ed. Spain: Churchill Livingstone; 2003: p. 613-20.

PMid: 14524363

2. Lum GM. Urinary tract infection. In: Hay WW Jr, Levin MJ, Sondheimer JM, Deterding RR, editors. Current Diagnosis and Treatment in Pediatrics, $18^{\text {th }}$ ed. McGraw-Hill Medical Publishing Division; 2006: 705-7.

3. Schlager TA. Urinary tract infections in children younger than 5 years of age: epidemiology, diagnosis, treatment, outcome and prevention. Paediatric Drugs 2001; 3: 21927. http://dx.doi.org/10.2165/0012807220010303000004

PMid: 11310718
4. Engorn B, Flerlage J. The Harriet Lane Handbook $20^{\text {th }}$ ed. Part III: Diagnostic and Therapeutic Information; 2014. 441- 2.

5. Ghaemi S, Feshraki RJ, Kelishadi R. Late onset jaundice and urinary tract infection in neonates. Indian Journal of Pediatrics 2007; 74(2):13941.

http://dx.doi.org/10.1007/s12098-007-0006-1 PMid: 17337825

6. Ginsburg CM, McCracken GH, Jr. Urinary tract infections in young infants. Pediatrics 1982; 69(4):409-12.

PMid: 7070887

7. Panahi Y, Bieraghdar F, Moharamzad Y, Matinzadeh ZK, Einollahi B. Incidence of urinary tract infections in febrile children in a 2 year period in Tehran, Iran. Tropical Doctor 2008; 38(4):247-9.

http://dx.doi.org/10.1258/td.2008.070356

PMid: 18820202

8. Cohen M. The first urinary tract infection in male children. American Journal of Diseases of Children 1976; 130:810-13.

http://dx.doi.org/10.1001/archpedi.1976.021200 90020004

9. Chow CB, Yau FT, Leung NK. Symptomatic urinary tract infection in Hong Kong Children. Journal Hong Kong Medical Association 1988; 40(4):276-80.

10. Siegel SR, Sokeloff B, Siegel B. Asymptomatic and symptomatic urinary tract infection in infancy. American Journal of Diseases of Children 1973; 125:45-7.

http://dx.doi.org/10.1001/archpedi.1973.041600 10025006

11. Drew JH, Acton CM. Radiological findings in newborn infants with urinary infection. Archives of Disease in Childhood 1976; 51:628-30.

http://dx.doi.org/10.1136/adc.51.8.628

12. Saleh SI, Tuhmaz MM, Sarkhaouh MY, ELGhawabi MA. Urinary tract infection in infants and children in Al-Jahra Area, Kuwait: An overview. Kuwait Medical Journal 2003; 35(1):31-5. 